Leader M. Shearer (Bridgnorth), and Flight Lieutenant I. V. Anderson (Northolt) for their valuable assistance, and to Mrs. J. M. Brown for technical help. We are indebted to the Director-General of the Royal Air Force Medical Services for permission to carry out these trials.

REFERENCES

Bull, D. R., and Burnet, F. M. (1943). Med. J. Aust., 1, 389. Burnet, F. M. (1942). Ibid., 1, 673.

- (1943). Ibid., 1, 385.

Chalkina, O. M. (1938). Arkh. biol. nauk., 52, 126

Isaacs, A., Negroni, G., and Tyrrell, D. A. J.'(1957). Lancet, 2, 886.

- and Roden, A. T. (1956). Ibid., 2, 697.

Mawson, J., and Swan, C. (1943). Med. J. Aust., 1, 394.
Meiklejohn, G. (1960). J. Amer. med. Ass., 172, 1354.

Pereira, M. S. (1958). Lancet, 2, 668.

Smorodintsev, A. A. (1960). Amer. J. publ. Hlth, 50, 40.

- Drobyshevskaya, A. I., Ostrovskaya, S. M., and Shishkina, O. I. (1937). Sovet. Vrach. Zhwr., 41, 403 .

- Tushinsky, M. D., Drobyshevskaya, A. I., Korovin, A. A., and Osetroff, A. I. (1937). Amer. J. med.'Sci., 194, 159.

and Zhdanov, V. M. (1957). Prob. Virol., 2, 65.

W.H.O. Technical Reports (1959). No. 170. Expert Committee on Respiratory Virus Disease.

Van der Veen, J., and Mulder, J. (1950). Studies on the Antigenic Composition of Human Influenza Virus A Strains. Stenfert Kroese, Leyden.

Vogel, J., and Shelokov, A. (1957). Science, 126, 358.

Zhdanov, V. M., and Solov'ev, V. D. (1952). Cited by V. M. Zhdanov in Uchenie o Grippe, 1958, chap. 10, Sect. 89. Znanie, Moscow.

\title{
INACTIVATED INFLUENZA VACCINE IN AN INDUSTRIAL UNDERTAKING
}

BY

\author{
G. J. FORTUIN, M.D. \\ Deputy Director
}

\author{
G. C. SOETERS, M.D. \\ Senior Medical Officer
}

\section{AND \\ A. VAN BEEK \\ Statistician}

Influenza must be regarded as a serious disease. The mortality it occasions is difficult to determine exactly, because a diagnosis of influenza can never be made with certainty on the basis of clinical observation alone.

Figures for excess mortality during pandemics and epidemics reveal that, though greatly reduced by progress in methods of treatment, the number of deaths caused by the disease is still fairly large. ${ }^{1-3}$ During the 1957 pandemic the death rate in the Netherlands, Britain, and the U.S.A. was 1 per 2,000 to 4,000 head of population. ${ }^{4-6}$ These high death rates are by no means confined to pandemic years but also occur during ordinary epidemics, as will be clear from Table $I^{7}{ }^{7}$ The drastic effect of influenza on sick-absence figures is evident from Fig. 1.

TABLE I.-Deaths from Influenza in England and Wales. Uncorrected Notifications for the First Quarters of the Last Five Years

\begin{tabular}{|c|c|c|c|c|c|}
\hline Number of deaths & $\begin{array}{c}1957 \\
361\end{array}$ & $\begin{array}{l}1958 * \\
2,093\end{array}$ & $\begin{array}{l}1959 * \\
7,098\end{array}$ & $\begin{array}{l}1960 \\
504\end{array}$ & $\begin{array}{l}1961 * \\
6,377\end{array}$ \\
\hline
\end{tabular}

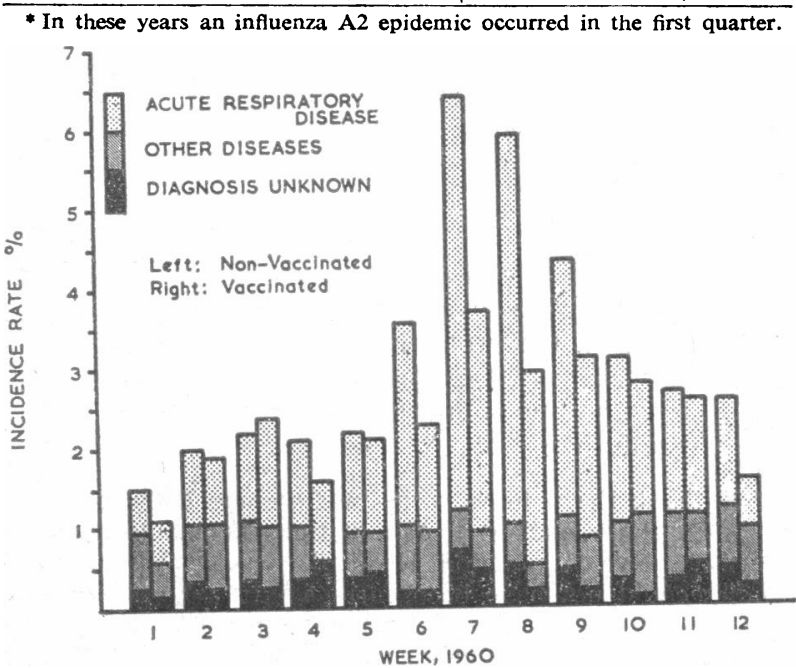

FIG. 1.-Incidence rate of acute respiratory diseases, other diseases with recorded diagnoses, and absences with diagnoses unknown in the group $1-1$, males $(1,779$ vaccinated, 8,222 nonvaccinated) during weeks $1-12$ of 1960 (see below, p. 1044).
In view of its high mortality and morbidity rates, determined action against influenza is called for. Vaccination is so far the only form of prevention the effectiveness of which has been demonstrated.

In practice there is a great deal of difficulty in proving that influenza vaccinations have actually yielded positive results: the clinical picture may be so similar to those of other acute diseases of the respiratory passages that differential diagnosis is possible only with the aid of complicated and costly laboratory tests, such as those whereby the virus is shown to be present in garglings or whereby antibodies are demonstrated in the blood. It has been possible, in investigations in which these methods were employed, to demonstrate whether vaccination has or bas not been effective in a given case. Vaccination against influenza is at present thought to be effective in 65 to $75 \%$ of cases. ${ }^{8-22}$

In circumstances where vaccination of industrial employees is undertaken as a routine, elaborate laboratory methods are impracticable and an attempt must be made to ascertain the effect of the vaccinations in some other manner. One obvious yardstick is sickness absence. We have acquired some experience in the use of it since 1949, in which year workers in the Dutch Philips factories were vaccinated against influenza for the first time.

It has been found that a number of requirements must be satisfied if the sick-absence method is to provide reliable results.

1. The recording of the sick-absence data must be absolutely accurate.

2. Absence due to influenza cannot itself be made the yardstick, as it is practically impossible to diagnose the disease with a sufficient degree of certainty.

3. Absence due to acute respiratory diseases cannot be taken as a yardstick either, unless the number of spells recorded under the heading "diagnosis unknown" is sufficiently small.

4. The spells of sick absence must be recorded for males and females separately, as the absence rates for the two sexes may differ considerably (see Table II).

5. Absences must be recorded by age-groups, because young people tend to be absent more often than older 
people (Table II). The latter, however, are away for much longer periods than young people are. Furthermore, absences on account of acute respiratory diseases are not always equally distributed over the age-groups (Table II).

TABLE II.-Incidence Rate of Acute Respiratory Diseases During the Influenza A2 Pandemic, 1957, and the Influenza A2 Epidemic, 1960, in Groups of Non-vaccinated Philips Workers (Eindhoven) Computed for Various Age-groups

\begin{tabular}{|c|c|c|c|c|c|c|c|}
\hline & Age-groups : & $\begin{array}{l}\text { All } \\
\text { Ages }\end{array}$ & $15-24$ & $25-29$ & $30-34$ & $35-44$ & $45-65$ \\
\hline $\begin{array}{c}1957 \\
\text { weeks 36-44 }\end{array}$ & \begin{tabular}{|l|} 
Males $(10,951)$ \\
Females $(3.580)$
\end{tabular} & $\begin{array}{l}34.1 \\
51 \cdot 5\end{array}$ & $\begin{array}{l}52.8 \\
62.0\end{array}$ & $\begin{array}{l}33 \cdot 2 \\
40 \cdot 7\end{array}$ & $\begin{array}{l}29 \cdot 5 \\
43 \cdot 4\end{array}$ & $\begin{array}{r}33 \cdot 0 \\
23 .\end{array}$ & $7^{*} 25 \cdot 5$ \\
\hline $\begin{array}{c}1960 \\
\text { weeks 4-12 }\end{array}$ & $\begin{array}{l}\text { Males }(8,222) \\
\text { Females }(2,018)\end{array}$ & $\begin{array}{l}22 \cdot 2 \\
22 \cdot 9\end{array}$ & $\begin{array}{l}19.9 \\
22.9\end{array}$ & $\begin{array}{l}25 \cdot 2 \\
22 \cdot 9\end{array}$ & $\begin{array}{l}26 \cdot 8 \\
22 \cdot 0\end{array}$ & $22 \cdot 2$ & $\begin{array}{l}123 \cdot 5 \\
25 \cdot 0^{*}\end{array}$ \\
\hline
\end{tabular}

* The groups of females over 35 years of age were too small to yield useful figures in the separate groups.

6. The groups chosen for observation should comprise a certain minimum number of individuals ; in small groups the relatively large statistical fluctuations in sick-absence figures may completely mask the results of vaccination, if any.

It is practically impossible to demonstrate that vaccination has or has not had any effect in groups comprising fewer than 100 persons. In groups comprising 100 to 500 persons it is sometimes possible to draw sufficiently reliable conclusions from the data. Preferably, however, the groups should be made up of at least 1,000 persons (see Table IV).

\section{Vaccination Programme}

In December, 1959, employees of Philips factories in the Netherlands were offered an opportunity of being vaccinated against influenza by their industrial physicians. Vaccination consisted in a subcutaneous injection of $1 \mathrm{ml}$. of the following inactivated vaccine:

Influenza virus vaccine, by Duphar

$$
\left.\begin{array}{lll}
\text { A2/Japan/305/1957 } & \ldots & 78 \% \\
\text { B1/Johannesburg/1958 } & \ldots & 22 \%
\end{array}\right\}
$$

No serious local or general reactions were observed.

The Philips Health Centre at Eindhoven maintains continuous records, for employees in these factories, of absences from work due to diseases falling under the provisions of the Sickness Act. The index used to determine the onset of the influenza epidemic and thereby the observation period is the weekly average of the point prevalence rate $(313)^{*}$ - that is, the average proportion of workers absent because of sickness; it is referred to as the P.P.R. The present study covers 35 groups, 18 of which are made up of men and 17 of women; each of these groups contains both vaccinated and non-vaccinated persons. The effectiveness of vaccination was determined for each group separately.

In the early part of 1960 an influenza epidemic occurred, caused by a virus of the A2 type whose antigenic composition proved to be identical to that of the A2 virus of which use had been made in the vaccine (Professor J. Mulder, Leyden University).

\section{Periods of Observation}

During the epidemic the P.P.R.s of 27 groups reached a peak significantly higher than the relevant average P.P.R. levels. For 18 of these groups the peak occurred in week 8 (February 22 to 28,1960 , inclusive); for nine of them it occurred in the weeks immediately preceding or following. The index used to determine the effect of vaccination is the incidence rate $(210),{ }^{*}$ abbreviated I.R., that being the number of spells of absence (irrespective of diagnosis) beginning during a specific week, expressed as a percentage of the number of persons under observation. The I.R. attains its peak some days before the P.P.R. does, and with this fact in mind we chose for each group a period of observation that included the week in which that particular group's P.P.R. reached a peak, and the two preceding weeks and the week following. Weeks $6,7,8$, and 9 constituted the observation period chosen for groups whose P.P.R. showed no pronounced peak.

\section{Yardstick Taken for Effect of Vaccination}

During an influenza epidemic the I.R. is made up of two components: one, the basic incidence rate, or B.I.R., relates to absences not caused by influenza, either directly or indirectly; the other component, the extra incidence rate, or E.I.R., relates to absences caused by influenza. Any effect the vaccination may have will manifest itself in the E.I.R., not in the B.I.R. We thus have the following arithmetical relationships (see Fig. 2).

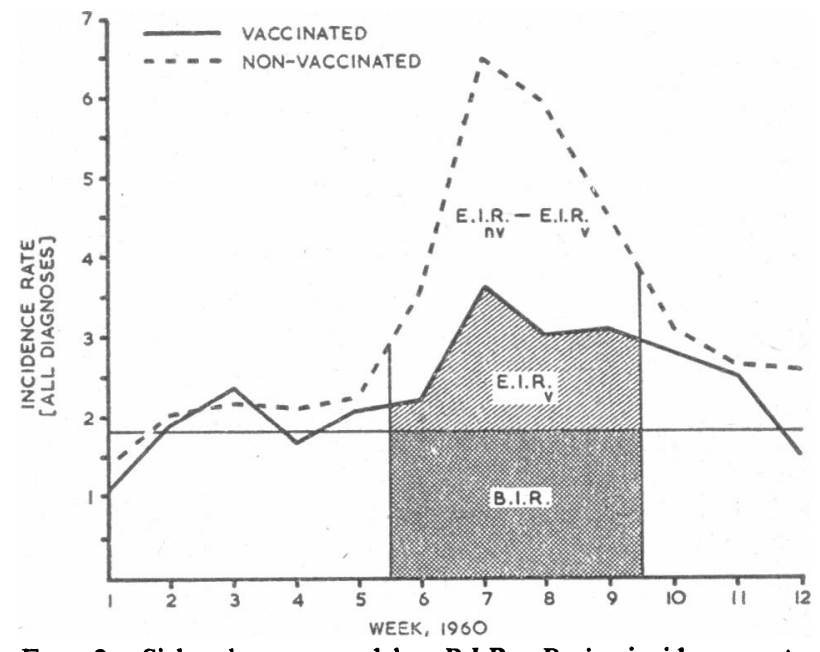

Fig. 2.-Sick absence model. B.I.R. = Basic incidence rate. E.I.R.v = Extra incidence rate in vaccinated groups. E.I.R.nv $=$ Extra incidence rate in non-vaccinated groups. I.R.v =lncidence rate in vaccinated group = B.I.R.+E.I.R.v. I.R. $\mathrm{nv}=$ Incidence rate in non-vaccinated groups $=$ B.I.R. + E.I.R.nv.

For vaccinated persons

I.R.v = B.I.R. + E.I.R.v and E.I.R.v $=$ I.R.v.$_{v}$ - B.I.R.

For persons who have not been vaccinated

I.R. ${ }_{n v}=$ B.I.R. + E.I.R. ${ }_{n v}$ and E.I.R.nv $=$ I.R. $\cdot n v-$ B.I.R.

I.R.v and I.R. $n v$ values over the relevant observation period were determined for each of the 35 groups. A basic component (B.I.R.) was worked out separately for each of the 35 groups by taking the average of weekly incidence rates over the whole year 1959; the B.I.R. level of the groups for males ranged from 1.00 to 3.30 , those for females from 2.00 to 5.90 (see Table III). It was now possible to use the above formulae to obtain an E.I.R.v and an E.I.R. ${ }_{\text {vv }}$ for each group (see Table III). It was decided to define the effect of vaccination as the relative reduction ( $R)$, expressed as a percentage, in the extra incidence rate (see Table III).

$$
\text { R=100 (E.I.R. }{ }_{n v}-\text { E.I.R. } v \text { )/E.I.R. } n v
$$

*The numbers in parentheses refer to the numbers quoted in the Report of the Sick Absence Statistics Committee of the Permanent Committee and International Association on Occupational Health. Proceedings, Thirteenth International Congress on Occupational Health. Book Craftsmen Associates, New York. 1961. 


\section{Possible Errors Involved in $\mathbf{R}$}

Those employees who agreed to be vaccinated did so quite voluntarily, so that assignment to the class of vaccinated persons was not on the basis of random sampling. There is therefore no guarantee that vaccinated and non-vaccinated persons have the same behaviour pattern in regard to sick absence. The question arises, then, whether it is permissible to assume that vaccinated persons had the same B.I.R. as nonvaccinated persons in the same group.

In order to cast some light on this matter, specific incidence rates in respect of $(a)$ acute respiratory diseases, $(b)$ all other diseases with recorded diagnoses, and $(c)$ absence-causing sickness with diagnosis unknown were calculated separately for the vaccinated and nonvaccinated members of each of the 35 groups over the weeks 1 to 12, inclusive, of 1960 . Fig. I shows the values obtained for the largest group (comprising 10.001 men, of whom 1,779 had been vaccinated and 8,222 had not); in which incidentally, the percentage of absences with diagnosis unknown was the lowest. Values for the other groups presented the same general picture with larger weekly fluctuations in the small groups. We feel entitled to conclude that there is nothing in our statistical material to suggest that the difference in B.I.R. between vaccinated and non-vaccinated persons is such as to invalidate our findings in regard to the effectiveness of vaccination.

It is also possible that no one in a given group contracted influenza; this freedom from the disease would also vitiate the accuracy of $R$. Three of the 35 groups showed no increase in P.P.R. during the influenza period (Part I of Table IV). Nevertheless, chance events are likely to give rise to differences between E.I.R.v and E.I.R. nv values calculated for these groups; $R$ values based thereon will not, of course, reflect the effect of vaccination.

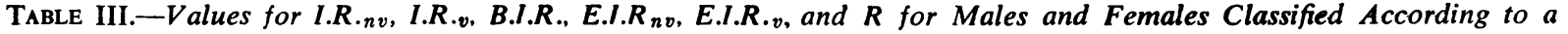
Number of Different Dutch Philips Factories (1959-60)

\begin{tabular}{|c|c|c|c|c|c|c|c|c|c|c|c|c|}
\hline \multirow{2}{*}{$\begin{array}{l}\text { Weekly-Paid } \\
\text { Workers per } \\
\text { Factory }\end{array}$} & \multicolumn{6}{|c|}{ Males } & \multicolumn{6}{|c|}{ Pemales } \\
\hline & I.R. $\mathbf{n V}$ & I.R.V & B.I.R. & E.I.R.Rv & E.I.R.V & $\mathrm{R} \%$ & I.R.nV & I.R.V & B.I.R. & E.I.R.nv & E.I.R.V & $\mathbf{R} \%$ \\
\hline 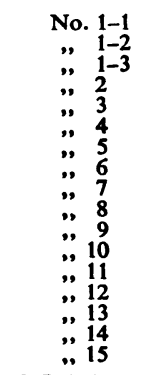 & $\begin{array}{l}5.13 \\
5.71 \\
7.52 \\
5.11 \\
4.94 \\
6.93 \\
7.07 \\
3.76 \\
8 \cdot 16 \\
6.49 \\
5.86 \\
6.22 \\
7.14 \\
7.62 \\
4.94 \\
4.71 \\
6.40\end{array}$ & $\begin{array}{l}2.99 \\
3 \cdot 18 \\
4.35 \\
3 \cdot 10 \\
2 \cdot 10 \\
3 \cdot 66 \\
4 \cdot 22 \\
3.20 \\
5 \cdot 15 \\
3.09 \\
5 \cdot 30 \\
4.99 \\
3.41 \\
6.34 \\
4 \cdot 12 \\
3.68 \\
4 \cdot 23\end{array}$ & $\begin{array}{l}1 \cdot 80 \\
2 \cdot 20 \\
3 \cdot 30 \\
2 \cdot 60 \\
2 \cdot 10 \\
2 \cdot 20 \\
3 \cdot 10 \\
1.90 \\
1 \cdot 80 \\
1.00 \\
2 \cdot 10 \\
2 \cdot 10 \\
2 \cdot 40 \\
2 \cdot 60 \\
2 \cdot 70 \\
2 \cdot 80 \\
2 \cdot 30\end{array}$ & $\begin{array}{l}3.33 \\
3.51 \\
4.22 \\
2.51 \\
2.84 \\
4.73 \\
3.97 \\
1.86 \\
6.36 \\
5.49 \\
3.76 \\
4.12 \\
4.74 \\
5.02 \\
2.24 \\
1.91 \\
4.10\end{array}$ & $\begin{array}{l}1.19 \\
0.98 \\
1.05 \\
0.50 \\
0 \\
1.46 \\
1.12 \\
1.30 \\
3.35 \\
2.09 \\
3.20 \\
2.89 \\
1.01 \\
3.74 \\
1.42 \\
0.88 \\
1.93\end{array}$ & $\begin{array}{r}64.3 \\
72.1 \\
75.1 \\
80.0 \\
100.0 \\
69.1 \\
71.8 \\
30.1 \\
47.3 \\
61.9 \\
14.9 \\
29.8 \\
78.7 \\
25.5 \\
36.6 \\
53.9 \\
52.9\end{array}$ & $\begin{array}{r}4.98 \\
4.61 \\
10.19 \\
4.96 \\
4.18 \\
5.47 \\
6.47 \\
40.30 \\
10.92 \\
3.77 \\
3.99 \\
5.45 \\
10.29 \\
15.24 \\
5.74 \\
5.97 \\
7.33\end{array}$ & $\begin{array}{r}4.64 \\
4 \cdot 70 \\
8 \cdot 62 \\
4 \cdot 62 \\
5.87 \\
-\overline{4} \cdot 64 \\
3.54 \\
5.78 \\
5.07 \\
16 \cdot 67 \\
4 \cdot 28 \\
3 \cdot 16 \\
8.89 \\
4 \cdot 30 \\
3.54 \\
5.02\end{array}$ & $\begin{array}{l}2.50 \\
2.80 \\
5.90 \\
3.00 \\
3.50 \\
3.40 \\
2.40 \\
4.40 \\
2.00 \\
2.80 \\
3.30 \\
2.30 \\
4.10 \\
3.50 \\
3.40 \\
3.60\end{array}$ & $\begin{array}{r}2.48 \\
1.81 \\
4.29 \\
1.96 \\
0.68 \\
3.07 \\
1.70 \\
6.52 \\
1.77 \\
1.19 \\
2.15 \\
7.99 \\
11.14 \\
2.24 \\
2.57 \\
3.73\end{array}$ & $\begin{array}{r}2.14 \\
1.90 \\
2.72 \\
1.62 \\
2.37 \\
1.24 \\
0.94 \\
1.38 \\
3.07 \\
13.87 \\
0.98 \\
0.86 \\
4.79 \\
0.80 \\
0.14 \\
1.42\end{array}$ & $\begin{array}{l}13 \cdot 7 \\
0 \\
36.6 \\
17 \cdot 3 \\
0 \\
59 \cdot 6 \\
44.7 \\
78.8 \\
0 \\
0 \\
54 \cdot 4 \\
89.2 \\
57.0 \\
64.3 \\
94.6 \\
61.9\end{array}$ \\
\hline $\begin{array}{c}\text { Monthly-paid } \\
\text { workers ... }\end{array}$ & $4 \cdot 59$ & 2.65 & 1.50 & 3.09 & $1 \cdot 15$ & 62.8 & 5.51 & 3.30 & $2 \cdot 40$ & $3 \cdot 11$ & 0.90 & $71 \cdot 1$ \\
\hline
\end{tabular}

TABLE IV.-Results of Vaccination against Influenza in 35 Groups (18 Groups of Men and 17 Groups of Women),

Each Consisting of Vaccinated and Non-Vaccinated Persons. The Dutch Philips Factories 1959-60. Total of 45,356 Persons Under Observation, of Whom 11,217 were Vaccinated

\begin{tabular}{|c|c|c|c|c|c|c|c|}
\hline & \multirow{2}{*}{$\begin{array}{c}\text { Factory } \\
\text { (Weekly- } \\
\text { paid } \\
\text { workers) }\end{array}$} & \multicolumn{2}{|c|}{$\begin{array}{c}\text { No. of Workers } \\
\text { Vaccinated }\end{array}$} & \multicolumn{2}{|c|}{$\begin{array}{l}\text { Percentage of Workers } \\
\text { Vaccinated }\end{array}$} & \multicolumn{2}{|c|}{$\begin{array}{c}\text { Computed Value and Confidence } \\
\text { Interval of } \mathbf{R}(\%)\end{array}$} \\
\hline & & $\mathbf{M}$ & $F$ & $\mathbf{M}$ & $\mathbf{F}$ & $\mathbf{M}$ & $\mathbf{F}$ \\
\hline $\begin{array}{l}\text { I. No increase of the } \\
\text { P.P R. in the } \\
\text { period of influenza }\end{array}$ & $\begin{array}{l}2 \\
3 \\
4 \dagger\end{array}$ & 39 & $\begin{array}{l}485 \\
166\end{array}$ & 28 & $\begin{array}{l}45 \\
54\end{array}$ & $69(0-100)$ & 17 (0-49) \\
\hline $\begin{array}{l}\text { II. No. of persons } \\
\text { vaccinated }<100\end{array}$ & $\begin{array}{c}1-3 \neq \\
5 \\
6 \\
7 \\
8 \\
9 \\
10 \\
11 \\
12\end{array}$ & $\begin{array}{l}87 \\
97 \\
29 \\
66\end{array}$ & $\begin{array}{r}98 \\
34 \\
89 \\
32 \\
7 \\
6 \\
87 \\
29 \\
54\end{array}$ & $\begin{array}{r}30 \\
41 \\
27 \\
8\end{array}$ & $\begin{array}{r}9 \\
19 \\
28 \\
53 \\
39 \\
7 \\
44 \\
63 \\
57\end{array}$ & $\begin{array}{l}72(33-93) \\
47(0-72) \\
62(0-100) \\
15(0-73)\end{array}$ & $\begin{array}{c}37(0-72) \\
60(0-100) \\
45(0-86) \\
79(0-100) \\
\text { N.R. } \\
54(0-90) \\
89(41-100) \\
57(7-80)\end{array}$ \\
\hline $\begin{array}{c}\text { III. No. of persons } \\
\text { vaccinated } 100-499\end{array}$ & $\begin{array}{r}1-1 \\
1-2 \\
1-3 \\
6 \\
13 \\
14 \\
15 \\
10 \\
2 \\
3 \\
11 \\
12\end{array}$ & $\begin{array}{l}247 \\
398 \\
208 \\
445 \\
437 \\
471 \\
306 \\
283 \\
178 \\
272\end{array}$ & $\begin{array}{l}399 \\
220 \\
\\
298 \\
103\end{array}$ & $\begin{array}{l}16 \\
26 \\
49 \\
40 \\
38 \\
32 \\
29 \\
42 \\
38 \\
40\end{array}$ & $\begin{array}{l}16 \\
25 \\
\\
53 \\
41\end{array}$ & $\begin{array}{c}75(60-91) \\
30(00-60) \\
37(0-75) \\
54(31-80) \\
53(33-70) \\
30(6-50) \\
80(62-97) \\
100(90-100) \\
79(61-95) \\
26(0-51)\end{array}$ & $\begin{array}{l}14(0-44) \\
\text { N.R. } \\
95(81-100) \\
62(6-89)\end{array}$ \\
\hline $\begin{array}{l}\text { IV. No. of persons } \\
\text { vaccinated }>500\end{array}$ & $\begin{array}{c}1-1 \\
1-2 \\
13 \\
\text { Monthly-paid } \\
\text { workers }\end{array}$ & $\begin{array}{l}1,779 \\
1,279 \\
1,349\end{array}$ & $\begin{array}{l}505 \\
635\end{array}$ & $\begin{array}{l}18 \\
20 \\
24\end{array}$ & $\begin{array}{l}52 \\
21\end{array}$ & $\begin{array}{l}64(56-72) \\
72(64-80) \\
63(52-72)\end{array}$ & $\begin{array}{l}64(34-83) \\
71(58-83)\end{array}$ \\
\hline
\end{tabular}

- Point prevalence rate (weekly average)-that is. the number of people absent owing to sickness per 100 workers under observation.

No female workers in factory 4

Weekly-paid workers in the Eindhoven factory were divided into three groups: 1-1, those living in Eindhoven; 1-2, those living in the Netherlands outside the town Eindhoven: 1-3, those living in Belgium. 


\section{Chance Element ; Confidence Intervals}

All the values of $\mathbf{R}$ calculated per group have been influenced to some extent by chance events, and consequently they will not be the same as the true index for the effect of vaccination, which we may call $R 1$. With a view to getting an impression of the influence of chance events, $95 \%$ confidence intervals were calculated; they are set out in Table IV. The limits have been fixed in such a way that there is a probability of $95 \%$ that $\mathrm{R} 1$ will fall within the interval worked out from the observed values.*

In general, chance events have a smaller influence on results obtained from large groups than those obtained from small groups. Hence $\mathbf{R}$ values calculated for large groups represent a more reliable estimate of $R 1$, the true measure of the effect of vaccination. The confidence interval for a large group is normally narrower than one for a small group, and so permits of more strictly formulated conclusions.

\section{Results}

The results for the $\mathbf{3 5}$ groups bave been assembled in Table IV. Part I relates to three groups in which sick absences failed to provide any evidence of an influenza epidemic. One remarkable fact is that an epidemic pattern was displayed by sick absences among men working in factories 2 and 3 but not by those of female employees in the same factories. The remaining 32 groups have been divided into three categories in accordance with the number of vaccinated persons they contain. It is clear that this number (if it represents less than $50 \%$ of employees) must be at least about 1,000 if the confidence interval is to be narrow enough to allow reasonably accurate conclusions to be drawn. It is seldom possible to draw such conclusions from data for smaller groups.

Results for the largest groups would indicate that the reduction in the E.I.R. can be assessed at 65 to $70 \%$. The results for the smaller groups are not in conflict with this assessment. This would imply that vaccination resulted in a saving of 8,200 working days, or a good 70 days per 100 vaccinated persons-a saving that amply makes up for the expense incurred.

It has not been possible to determine with sufficient certainty the influence exercised by age on the I.R.s of vaccinated and non-vaccinated persons during the fourweek observation periods.

\section{Summary}

The effect of an inactivated influenza vaccine on the " extra incidence rate" during an influenza epidemic was determined by studying sick absences in 35 groups, each made up of vaccinated and non-vaccinated persons and together comprising more than 45,000 persons, of whom more than 11,000 had been vaccinated.

The vaccination programme appears to have reduced extra sick absences by 65 to $70 \%$.

\section{REFERENCES}

1 Collins, S. D., Publ. Hlth Monogr., 1957, No. 48.

2 and Lebmann, J. L., ibid., 1953, No. 10.

s Deutschman, Z., Bull. Wld Hlth Org., 1953, 8, 633.

4 Mutschman, Z.' Bull. Wld Hith Org ,060, 22, 399.

5 Eickhoff, T C., Sherman, I. L., and Serfling, R. E., J. Amer. med. Ass., 1961, 176, 776.

*If one of the limits is either $0 \%$ or $100 \%$, this probability amounts to ahout $98 \%$; if the two limits are $0 \%$ and $100 \%$, then the probability is $100 \%$.
- Brit. med. J., 1959, 1, 490.

- 1961, 1, 1263

${ }^{8}$ Francis, T., jun., Bull. Wld Hlth Org.. 1953, 8, 725.

Heller, Körlof, B., Mörner, J., and Zetterberg, B., ibid. $1959,20,377$

Francis, T., jun., Ann. intern. Med., 1955, 43, 534.

Commission on Influenza, Armed Forces Epidemiological Board, Office of Commission on Influenza, School of Public Health. University of Michigan, Ann Arbor.

12 Vaccination Against Asian Influenza: Basis for Recommendations and Prelıminary Report on Efficacy, J. Amer. med. Ass., 1957, 165, 2055.

13 Davenport, F. M., Publ. Hlth Rep. (Wash.), 1958, 73, 133.

14 Hilleman, M. R., Flatley, F. J., Anderson, S. A., Luecking, M. L., and Levinson, D. J., J. Amer. med. Ass., 1958, 166 , 1134

15 Davenport, F. M., Mod. Med., 1958, 26, 115

16 Meiklejohn, G., and Morris, A. J., Ann. intern. Med., 1958, 49, 529.

17 Gundelfinger, B. F., Stille, W. T., and Bell, J. A., New Engl. J. Med., 1958, 259, 1005.

18 Jensen, K. E., Woodhour, A. F., and Bailey, A. A., J. Amer. med. Ass., 1960, 172, 1230.

19 Dull, H. Jensen, K. E., Rakich. J. H., Cohen, A. Henderson, D. A., and Pirkle, C. 1., ibid., 1960, 172, 1223. Henderson, D. A., and Pronkel, J. W., New Boger, W. P., Aaronson, 1 . Med., 1960, 262. 856.

21 Davenport, F. N., and Hennessy, A. V.. Viral Infections of Infancy and Childhood, 1960, edited by H. M. Rose, p. 145. New York Academy of Medicine (Section of Microbiology), Symposium No 10 Hoeber-Harper, New York.

22 Sigurjónsson, J., Sigurdsson, B., and Grimsson, H., Bull. Wld Hlth Org., 1959, 20, 401.

\section{COMBINED STEROID THERAPY OF FULMINATING ULCERATIVE COLITIS}

BY

\section{S. G. FLA VelL MATTS, M.B., Ch.B., M.R.C.P.Ed. \\ Senior Medical Registrar, Royal Hospital, Wolverhampton}

Fulminating ulcerative colitis is a serious emergency problem which fortunately confronts the clinician infrequently. However, when it does present, treatment must be urgent and immediate or the patient's life may be forfeit.

Of recent years there has been a change in the medical management of ulcerative colitis, and steroid therapy has been found to be useful in many cases (Truelove and Witts, 1955). Refinement and possibly improvement in treatment has been reported with the use of hydrocortisone intrarectally by slow infusion (Truelove, $1956,1957,1958$ ) and prednisolone intrarectally from a plastic bag in one injection (Matts, 1960a, 1960b, 1961a).

Reports of the use of steroids in fulminating colitis are few. In the series presented by Lennard-Jones and Vivian (1960) only seven cases were treated in the fulminating episode with large doses of either A.C.T.H. or cortisone. Only two of these were found to improve as a result of this treatment. Truelove $(1960 \mathrm{~b})$ reports more encouraging results using local hydrocortisone either alone or combined with systemic steroids. All his five cases reported in detail improved on treatment. Further, he cited a sharp fall in the in-patient mortality rate of ulcerative colitis patients during the years topical steroids had been used at the Radcliffe Infirmary. As the results of management of ulcerative colitis in general with steroids have been so good (Truelove, 1956, 1957, 1958, 1960a ; Watkinson, 1958; Matts, 1960a, 1960b, 1961a) it would appear that their use in fulminating colitis is worth considering. Accordingly a group of 12 patients have been treated with combined A.C.T.H. by injection and intrarectal prednisolone. 